
This report was prepared as an account of work sponsored by the United States Government. Neither the United States nor the United States Energy Research and Development Administration, nor any of their contractors, subcontractors, or their employees, makes any warranty, express or implied, or assumes any legal liability or responsibility for the accuracy, completeness or usefulness of any information, apparatus, product or process disclosed, or represents that its use would not infringe privately owned rights.

Printed in the United States of America

Available from

National Technical Information Service

U. S. Department of Commerce

5285 Port Royal Road

Springfield, Virginia 22161

Price: Printed Copy \$3.50; Microfiche $\$ 2.25$ 
DP- 1428

Distribution Category: UC-32

\section{OPTIMIZATION OF INSERVICE INSPECTION OF PRESSURE VESSELS}

by

L. M. Arnett

Approved by

J. W. Stewart, Research Manager

Computer Applications Division

Publication Date: August 1976

E. I. DU PONT DE NEMOURS AND COMPANY
SAVANNAH RIVER LABORATORY
AIKEN, SOUTH CAROLINA 29801

PREPARED FOR THE U. S. ENERGY RESEARCH AND DEVELOPMENT ADMINISTRATION UNDER CONTRACT ATI07-2!1 


\section{ABSTRACT}

Methods are developed for the calculation of the factor of improvement in the reliability of pressure vessels that can be obtained from the inservice inspection. The factor of improvement is the ratio of the probability of vessel failure with the preservice inspection only to the probability of vessel failure with preservice and inservice inspections. Failure of the vessel is defined as crack growth to the critical size or through the vessel wall as given by the theory of linear elastic fracture mechanics. The numerical results show that when all other conditions are held constant, the factor of improvement is nearly exponential with the number of inservice inspections. The number of inservice inspections are those in addition to the initial inspection and repair of cracks before the vessel is placed in service. When very conservative assumptions are made for all factors that affect the exponential relation, factors of improvement of approximately 8000 are expected for three inservice inspections, optimally spaced during the service life of the vessel.

For more reasonably assumed values, the factor of improvement is much larger, even in excess of $10^{13}$. These large factors assume $100 \%$ inspection of the vessel and are attained only when the schedule of the inservice inspections is optimized. The optimum schedules show large deviations from those in which the inspections are equally spaced throughout the service life of the vessel. In a typical case of three inservice inspections, the optimum schedule shows inspections at 8,27 , and $52 \%$ of the service life rather than 25,50 , and $75 \%$. In many instances, two inservice inspections, optimally placed, will produce a bigger factor of improvement than three inspections spaced at 25,50 and $75 \%$ of the service life. 


\section{CONTENTS}

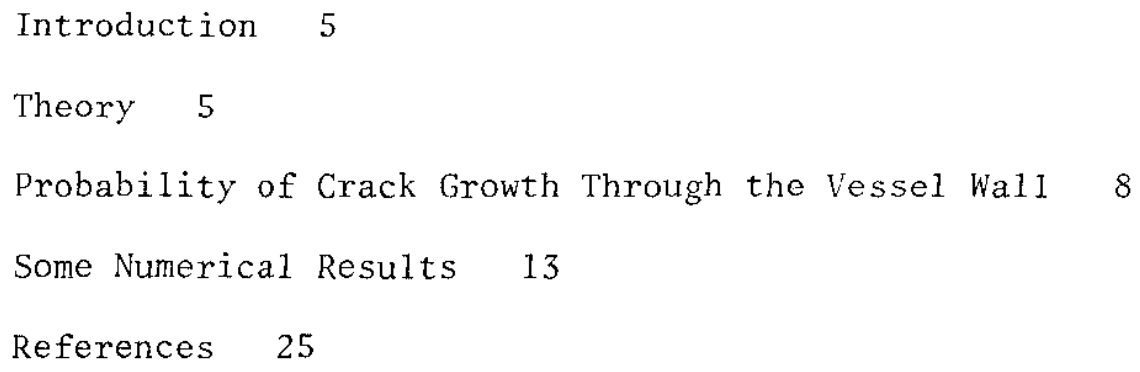

\section{LIST OF FIGURES}

1 Scheme of Calculations 11

2 Density Functions of Cracks in Vessel 15

3 Efficiency of Detection of Cracks 17

4 Factor of Improvement as Function of Iispection Time 19 
The work described in this report was performed while the author was temporarily assigned to the U.S. Atomic Energy Commission (later the U.S. Nuclear Regulatory Commission) in Bethesda, Maryland, from June 1973 to June 1975.

This material was also presented orally by the author at the conference on Nondestmuctive Evaluation in the Nuclear Industry conducted by the American Society for Metals, Technical Divisions and Activities at the Marriott Inn, Denver, Colorado, December 1-3, 1975. 


\section{INTRODUCTION}

The probability that a nuclear reactor vessel will fail during its service life from the growth of cracks due to fatigue cycling has been shown to be extremely sma11. ${ }^{1},{ }^{2}$ The probabilities shown in References 1 and 2 are generally in the range $(99 \%$ confidence) of no more than $10^{-5}$ to $10^{-6}$ for a dismuptive failure during one vessel-year. The discovery and subsequent repair of cracks in the vessel by inservice inspections will lower the probability of failure or increase the integrity of the vessel. Nuclear reactor vessels are inspected throughout their service life to achieve even lower probabilities of failure. This report presents an analysis and a calculational method of the merits of the inservice inspections of pressure vessels.

\section{THEORY ${ }^{3}$}

The following mathematical model of a probabilistic system is couched in general terms so as to avoid limitations of applicability that might otherwise result from restrictions to specific systems. It was anticipated during the development of these theories and methods that they would be applied to the probability that cracks in a vessel would grow to the critical size or through the wall of the vessel by the mechanisms postulated in the theory of linear elastic fracture mechanics.

A large number or large population of entities are given. Each entity is characterized by a vector of attributes, $\mathrm{X}$; each attribute is a continuous random variable defined as nonzero on the closed interval [XL, XU]. Furthermore, the number of attributes associated with each entity is no larger than a countable infinity and, in fact, has a Poisson diztribution with the parameter value, $\mathrm{m}$.

The original density function of the attributes, $x$, is

$$
f_{O}(x) \quad X L \leqslant x \leqslant X U
$$

$0 \quad$ otherwise 
The density function is censored by a systematic removal of individual values of the attributes, $x$, before the system is altered. Censoring with the probability expression, $g(x)$, which gives exactly the probability that a particular-valued attribute will escape removal, produces the following density function:

$$
f_{S}(x)=\frac{f_{0}(x) g(x)}{\int_{X L}^{X U} f_{O}(x) g(x) d x}
$$

The alteration of the system is such that the attribute, $X$, undergoes a transformation of value; that is, $x$ is transformed to $y$ by the function $y=t(x)$. This transformation is entirely deterministic; it has no probabilistic character associated with it.

The question of concern about this system is: Will a given entity possess a value, $y$, of the attribute, $x$, in excess of some critical value, $C_{1}$, or some maximum value, $C_{m}$, after a specified alteration? The answer can only be expressed in probabilistic terms because the values of $X$ are random variables. Thus, it is proper only to ask: What is the probability that an entity will possess a value, $y$, of $X$ in excess of $C_{v}$ or $C_{m}$ ? The critical value, $C_{V}$, or maximum value, $C_{m}$, is a property of the system and is independent of the transformation.

The concern is with the entity rather than the attribute; therefore it is necessary to form the density function of the maximum-valued attribute in each entity. This density function is given by

$$
f_{m}(x)=f_{s}(x) \cdot a m \cdot \exp [-a m(1-I)]
$$

where

$$
a m=m^{*} \int_{X L}^{X U} f_{0}(x) g(x) d x
$$

and

$$
I=\int_{x}^{X U} f_{s}(x) d x
$$



are:

- Form the density function of the maximum-valued attribute after transformation; i.e.,

$$
h_{m}(y)=f_{m}(x) \quad\left\{\frac{d x}{d y} \mid\right.
$$

and integrate for $y \geqslant C_{v}$, or $y \geqslant C_{m}$, or what is equivalent.

- Integrate $f_{m}(x)$ as follows:

$$
\int_{\min \left(x_{C_{v}}, x_{C_{m}}\right)}^{x U} f_{m}(x) d x
$$

where

$$
x_{C_{v}}=t^{-1}\left(C_{v}\right)
$$

and

$$
x_{C_{m}}=t^{-1}\left(C_{m}\right)
$$

A further question of possible interest is how is the probability that an entity possesses a value of the attribute, $X$, in excess of the critical or maximum value affected by an interruption and censoring of the density function of the attribute, $x$, at some intermediate point during this alteration?

This latter question is approached by exactly the same process as the original question. The density function $f_{s}(y)$ is set equal to $\mathrm{q}_{0}(\mathrm{y})$, and this series of " $\mathrm{q}$ " density functions is carried through the same set of manipulations as the set of "f" density functions. This two-step transformation will yield two probabilities, $P_{1}$ and $\mathrm{P}_{2}$, that are corbined to yield the overall probability for the total transformation as follows:

$$
\mathrm{P}_{\mathrm{T}}=1-\left(1-\mathrm{P}_{1}\right)\left(1-\mathrm{P}_{2}\right)
$$

$P_{T}$ will in general be less than that for the equivalent transformation without the intermediate censoring. 
The system can be transformed and censored any number of intermediate times:

$$
\mathrm{P}_{\mathrm{T}}=1-\underset{\mathrm{n}}{\prod_{i}}\left(1-\mathrm{P}_{\mathrm{i}}\right)
$$

PROBABILITY OF CRACK GROWTH THROUGH THE VESSEL WALL

The theory developed in the preceding section is now applied to calculate the probability that a crack initially present will grow to or beyond the critical size or through the thickness of the wall by the mechanisms postulated by linear elastic fracture mechanics. Further, the calculation is extended to the improved probability or benefit obtained when the vessel is inspected and repaired at intermediate times during its service life.

The first task is to select a specific expression for $f_{0}(x)$, the density function of cracks in the reactor vessel as it is manufactured. The number of cracks is assumed to decrease as the size of the crack increases. That is, there are more small cracks than there are large cracks. A simple density function that possesses this characteristic is the exponential density. However, this density has a domain from zero to infinity whose upper bound is surely beyond reality. No crack can be deeper than the wall thickness of the vessel. Although for calculational purposes, such an assumption might not be too bad, it is intuitively more satisfying to select a beta density function for $f_{0}(x)$. The beta density has finite upper and lower bounds. The upper limit is selected as 10 inches, the assumed thickness of the vessel. The lower bound need be only low enough so that the smaller crack never grows to critical or maximum size during any of the postulated service of the vessel. In this instance, the lower bound is selected as 0.2 inch. This selection avoids the necessity of having to judge how many cracks have sizes below the lower bound. The expression for $f_{0}(x)$ is taken to be

$$
f_{0}(x)=\frac{1}{B(\eta, \gamma)}(x-0.2)^{\gamma-1}(10-x)^{\eta-1} \frac{1}{9.8^{n+\gamma-1}}
$$

where

$$
B(\eta, \gamma)=\text { beta function of eta and gamma }
$$

This expression satisfies the requirement of a density function that its integral over the interval $[0.2,10]$ equals unity for all values of $\eta$ and $\gamma$. The beta density is rendered specific by the selection of values for $\eta$ and $\gamma$ to fit the assumed known distribution of cracks in the manufactured vessel. 
The next step is to select an expression for $g(x)$, which is the probability that a crack will escape detection during the nondestructive examination procedure. Again, this selection is arbitrary, needing only to fill the requirement that it be reasonable. The selection in this instance was

$$
g(x)=\exp \left[-G F(x-A L L)^{P X W}\right]
$$

where

ALL $=$ lower 1 imit of detection method

$\mathrm{GF}, \mathrm{PXW}=$ parameters

Because the average number of cracks, "m," i.e., those greater than 0.2 inch, is small for a given vessel, it is possible to simplify the equation presented in the previous section of theory. In particular,

$$
\operatorname{am} \cdot \exp [-\operatorname{am}(1-I)]
$$

in the expression for $f_{m}(x)$ can be set equal to "am." This is possible because $\exp \left[-a_{m}^{m}(1-I)\right]$ is very nearly equal to unity for a small value of "am." Further,

$$
a m=m \int_{0.2}^{10} f_{0}(x) g(x) d x
$$

and

$$
f_{m}(x) \cong m f_{0}(x) g(x)
$$

The transformation mentioned in the section on theory is now taken to be the growth of cracks during the stress cycling that the vessel undergoes during service. Small cracks get 1 arger, and possibly some cracks grow to sizes larger than critical or maximum. The amount of growth is given by the theory of linear elastic fracture mechanics. The relation used here is given by

$$
\frac{d N}{d a}=\frac{(1-R) K_{I C}-\Delta K_{I}}{c\left(\Delta K_{I}\right)^{n}}
$$


where

$$
\begin{aligned}
\Delta \mathrm{K}_{\mathrm{I}} & =(1-\mathrm{R}) \sigma(\pi \alpha)^{\frac{1}{2}} \mathrm{a}^{\frac{1}{2}} \\
\sigma & =\text { maximum stress during cycle } \\
\mathrm{K}_{\mathrm{IC}} & =\text { fracture toughness } \\
\mathrm{a} & =\text { crack depth } \\
\mathrm{N} & =\text { number of cycles } \\
\mathrm{R} & =\text { ratio, } \sigma(\min ) / \sigma(\max ) \\
\mathrm{c}, \mathrm{n}, \alpha & =\text { parameters }
\end{aligned}
$$

The integration of the above differential equation yields

$$
N=\frac{A}{2-n}\left[a^{(2-n) / 2}-a_{0}^{(2-n) / 2}\right]-\frac{B}{3-n}\left[a^{(3-n) / 2}-a_{0}^{(3-n) / 2}\right]
$$

where

$$
\begin{aligned}
a_{0} & =\text { depth of original crack } \\
a & =\text { depth of grown crack } \\
A & =\frac{2 K_{I C}}{c(1-R)^{n-1} \sigma^{n}(\pi \alpha)^{n / 2}} \\
B & =\frac{2 \sigma(\pi \alpha)^{\frac{1}{2}}}{c(1-R)^{n-1} \sigma^{n}(\pi \alpha)^{n / 2}}
\end{aligned}
$$

The critical size of the crack is given by

$$
a_{c}=\left(\frac{K_{I C}}{\sigma}\right)^{2} \frac{1}{\pi \alpha}
$$

This is the value of " $a$ " for which the numerator of $d N / d a$ equals zero or for which the rate of growth of the crack is infinite.

The equation for the crack size as a function of the number of cycles and the original size is nonlinear in crack size. Consequently, it cannot be solved by the usual finite methods. Specifically, no finite method will provide a value of " $a$ " when $a_{0}$ and $\mathrm{N}$ are given. However, in this instance, a Newton-Raphson method is used to obtain the desired solution. 
Figure 1 shows how all the formulas, assumed to fit a real case, are put together to yield the required result. The line at the top of XL to XU, or from 0.2 to 10 , is the domain of the original density function, $f_{0}(x)$. The inspection or censoring with subsequent repair does not change the domain nor does it change the sizes of any of the cracks. All that is changed is the number of cracks. The censored function is

$$
f_{S}(x)=\frac{f_{0}(x) g(x)}{\int_{0.2}^{10} f_{0}(x) g(x) d x}
$$

The denominator is just the fraction of cracks that remain after inspection and repair. The number of cracks that remain after inspection and repair is

$$
m \int_{0.2}^{10} f_{0}(x) g(x) d x
$$

When this latter quantity is put into the expression for $f_{S}(x)$ and the exponential factor is set equal to unity,

$$
f_{m}(x)=f_{0}(x) \cdot g(x) \cdot m
$$

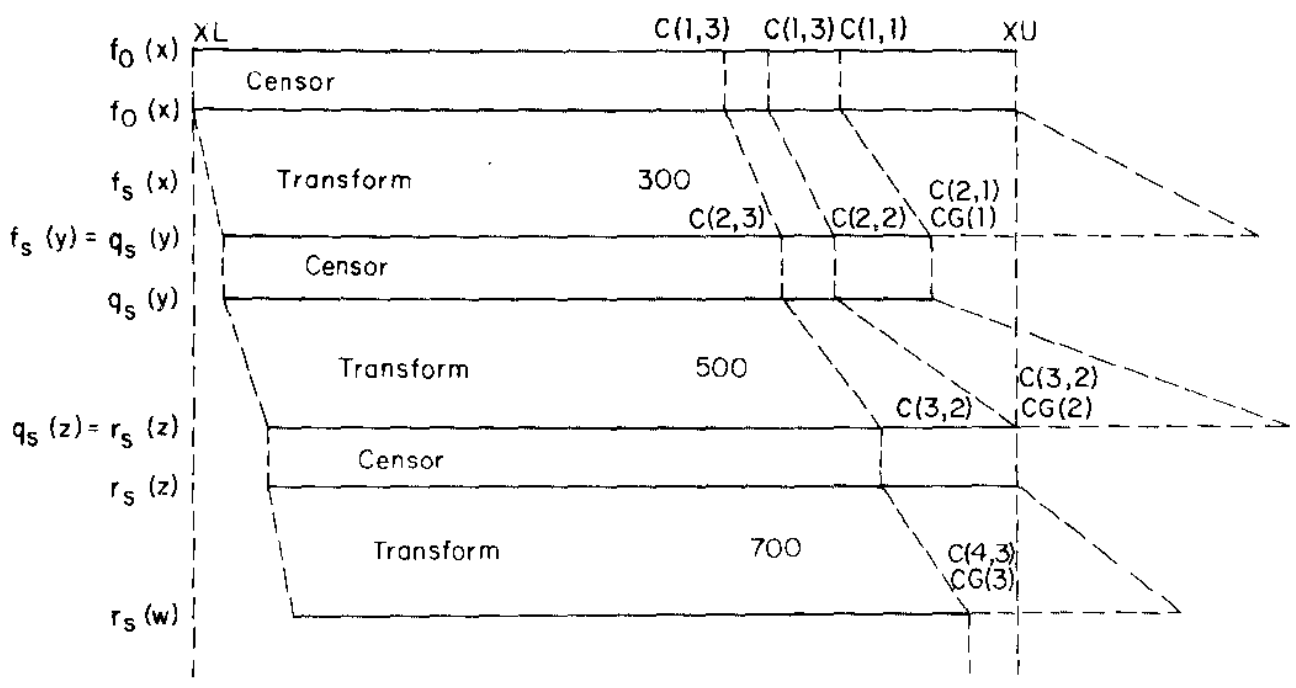

FIGURE 1. Scheme of Calculations 
Now, the fracture mechanics equation is solved for CG(1), which is the critical size crack for the material and stress level. If this value is larger than the thickness of the vesse1 wall, CG (1) is set equal to the wall thickness. Also, the equations are solved to obtain the size crack, $C(1,1)$, that will just grow to the critical size in the specified number of cycles. Thus, the probability that a given vessel will fail during this period is just

$$
\begin{aligned}
& p\{\text { vesse1 failure }\}=m \int_{C(1,1)}^{C G(1)} f_{m}(x) d x \\
& p\{\text { vesse1 failure }\}=m \int_{C(1,1)}^{C G(1)} f_{0}(x) g(x) d x
\end{aligned}
$$

If the vessel is inspected and repaired at the end of this first period and is followed by a second period of stress cycling, there is a second probability of failure due to cracks smaller than $C(1,1)$ growing to critical. Solution of the fracture mechanics equation yields a size, $C(1,2)$, for cracks that will grow to critical in two prescribed cycling periods. Likewise, cracks between sizes $C(1,3)$ and $C(1,2)$ will grow to critical in a third period.

The transformation due to crack growth short of critical in any period is treated by making the mathematical change of variable. For example, a crack size, $x$, in the interval $[C(1,2)$, $C(1,1)]$ grows during the first period to a size, $y$, in the interval $[C(2,2), C(2,1)]$. Consequently, the probability of failure during the second period is

$$
P\{\text { vessel failure }\}=m \int_{C(2,2)}^{C G(2)} f_{0}(x) g(x)\left|\frac{d x}{d y}\right| g(y) d y
$$

This expression is more easily evaluated by calculation of its equivalent,

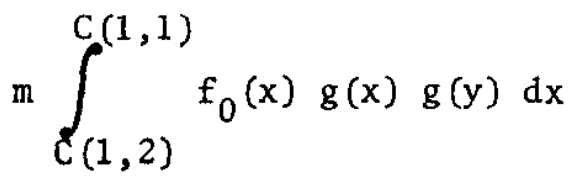

If the second transformation produces a change from $y$ to $z$ 
in crack size, then the probability of failure during the third period is

$$
P\{\text { vessel failure }\}=\int_{C(3,3)}^{C G(3)} f_{0}(x) g(x)\left|\frac{d x}{d y}\right| g(y)\left|\frac{d y}{d z}\right| g(z) d z
$$

Again,

$$
P\{\text { vessel failure }\}=m \int_{C(1,3)}^{C(1,2)} f_{0}(x) g(x) g(y) g(z) d x
$$

Each of the probabilities for each interval between inspections can be calculated. The $f_{0}$ and all of the $g$ functions are assumed to fit known data. The $C$ and $C G$ crack sizes are given by the theory of linear elastic fracture mechanics.

If $P_{i}$ is the probability of failure during the $i^{\text {th }}$ period, then the probability of failure during some period is

$$
P\{\text { vesse } 1 \text { failure sometime }\}=1-\underset{n}{\Pi}\left(1-P_{i}\right)
$$

When the $P_{i}$ are all small, as is normally the case, the above expression reduces to approximately

$$
\sum_{n} P_{i}
$$

Finally, this last quantity is compared to the probability of failure when there are no intermediate inspections but only the preservice inspection to obtain a value for the factor of improvement that results from the periodic inspections.

SOME NUMERICAL RESULTS

Four computer programs were written in FORTRAN for the computations described in the previous section.

Computer Program I is used to calculate eta and gamma in the beta function of the cracks as they occur in the as-manufactured vesse1. The function is always assumed to be of the form

$$
f_{0}(x)=\frac{1}{B(n, y)}(x-0.2)^{\gamma-1}(10-x)^{n-1} \frac{1}{9.8^{\eta+\gamma-1}}
$$


This function says that the cracks are all equal to or greater than 0.2 inch and equal to or less than 10 inches. The upper limit is the assumed wall thickness of the vessel. If the vessel under consideration has a wall thickness other than 10 inches, the density function must be altered accordingly. The lower limit of 0.2 inch is arbitrary, only small enough so that no smaller cracks can grow to the critical or maximum size during the service life of the vessel. The parameters, $\eta$ and $\gamma$, are shape parameters that determine how much of the density falls in specific areas. For example, when it is assumed that there are 18 cracks larger than 0.2 inch in 1000 vessels distributed as follows:

$$
\begin{aligned}
18 \text { cracks } & \geqslant 0.2 \text { inch } \\
8 \text { cracks } & \geqslant 0.5 \text { inch } \\
3 \text { cracks } & \geqslant 1.0 \text { inch }
\end{aligned}
$$

Then

$$
\int_{0.5}^{1.0} f_{0}(x) d x=\frac{5}{18}=0.2778
$$

and

$$
\int_{1.0}^{10} f_{0}(x) d x=\frac{3}{18}=0.1667
$$

The computer program produces values of these two integrals for various combinations of $n$ and $\gamma$. If $n=14.7$ and $\gamma=0.66$, the integrals are 0.2794 and 0.1671 . Two sets of $\eta$ and $\gamma$ were selected for illustrative calculations. These two choices are designated as follows:

$\begin{array}{lllll}\text { Density } & \eta & \gamma & \text { Integral 1 } & \text { Integral 2 } \\ 1 & 14.7 & 0.66 & 0.2794 & 0.1671 \\ 2 & 9.8 & 0.60 & 0.2649 & 0.2486\end{array}$

Thus, density 2 is more conservative than density 1 because a larger fraction of cracks are in the interval [1.0 to 10.0].

Two choices were also made for the mean number of cracks larger than 0.2 inch in the manufactured vessels. They are, respectively, 0.018 and 0.050 . This means that 1000 vessels have, respectively, 18 and 50 cracks 1 arger than 0.2 inch. The following table shows the distributions for these assumptions: 
Crack $(x)$

inch

$\geqslant 0.2$

$\geqslant 0.5$

$\geqslant 1.0$ (x), $\frac{18 \text { Cracks/1000 Vessels }}{\text { Density } 1 \text { Density } 2}$

18

8.04

3.01
18

9.24

4.47
50 Cracks 11000 Vessels

Density 1 Density 2

$50 \quad 50$

$22.33 \quad 25.68$

$8.36 \quad 12.43$

Figure 2 shows the characteristics of these two density functions. Also, the censored density function after the initial preservice inspection of the vessel is shown in Figure 2.

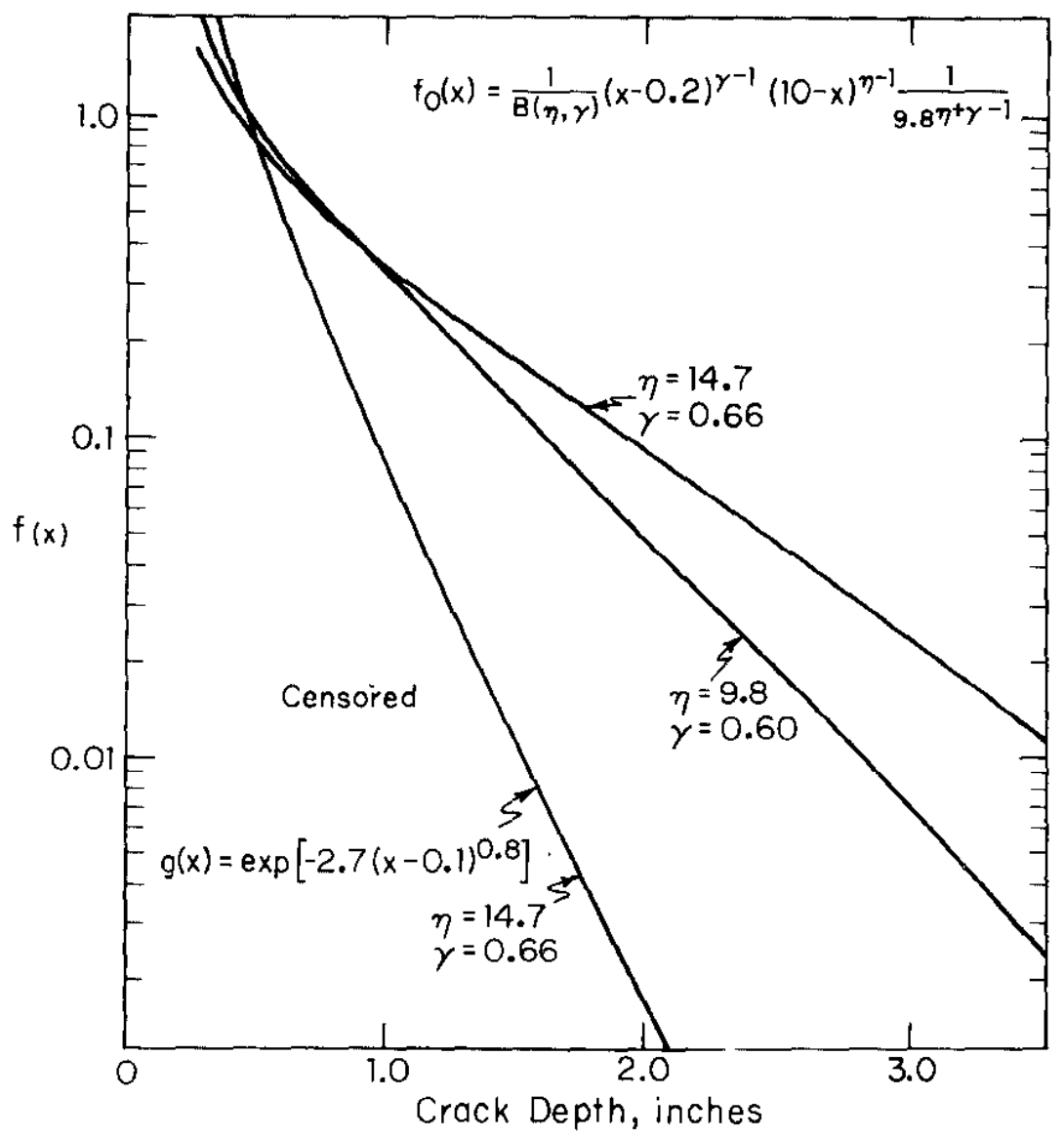

FIGURE 2. Density Functions of Cracks in Vessel 
The inspection of the vessel for cracks is not likely to be perfect. There is some probability that a crack, no matter how large, will escape detection and will not be repaired. This situation is expressed as

$$
g(x)=\exp \left[-G F(x-A A L)^{P X W}\right]
$$

where

$$
\begin{aligned}
\text { ALL } & =\text { lower } 1 \text { imit of detection } \\
G F & =\text { parameter } \\
\text { PXW } & =\text { parameter }
\end{aligned}
$$

The quantity $g(x)$ is the probability that a crack of size $x$ will escape detection.

Two sets of parameters with the following designations were used for the calculations:

$$
\begin{aligned}
& \text { Set } 1 \quad \text { ALL }=0.1 \quad \text { Set } 2 \quad \text { ALL }=0.1 \\
& \begin{array}{rlr}
\mathrm{GF}=2.0 & \mathrm{GF}=2.7
\end{array} \\
& \text { PXW }=0.5 \quad P X W=0.8
\end{aligned}
$$

The following table shows values of $g(x)$ for these two sets" and various values of $x$, the crack depth:

$\begin{array}{rll}\begin{array}{l}\text { Crack } \\ \text { inch }\end{array} & \text { Pr) } & \\ & \text { Procedure } & \\ 0.1 & 1.000 & 1.000 \\ 0.2 & 0.531 & 0.652 \\ 0.5 & 0.282 & 0.273 \\ 1.0 & 0.150 & 0.084 \\ 2.0 & 0.063 & 0.0110 \\ 5.0 & 0.0119 & 6.59 \mathrm{E}-05 \\ 10.0 & 0.00185 & 4.58 \mathrm{E}-08\end{array}$

The inspection procedure 2 is obviously better in detecting large cracks that could possibly grow through the wall of the vessel. In fact, procedure 1 is rather "poor" because it presumes that large cracks can very easily be missed. Figure 3 shows each of these two functions. 


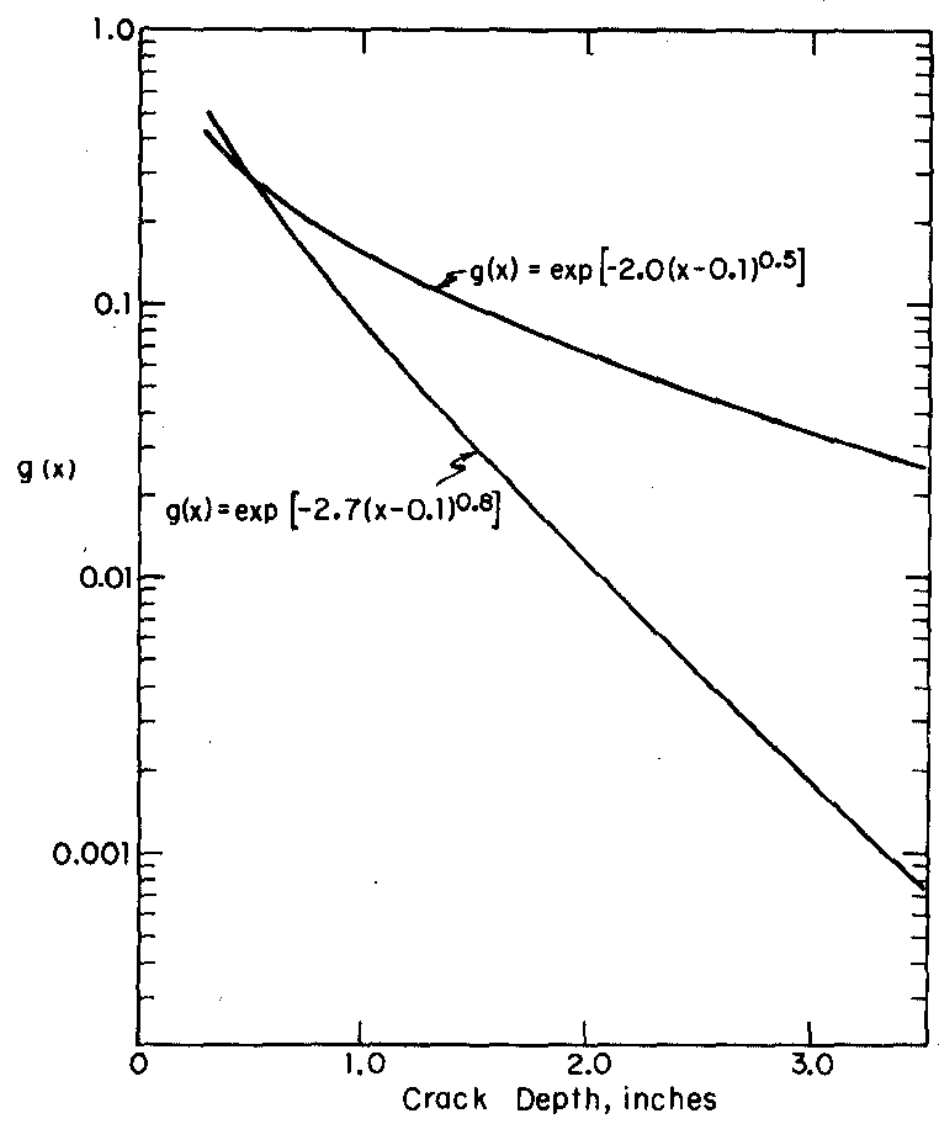

'FIGURE 3. Efficiency of Detection of Cracks

Two sets of parameters were used for the fracture mechanics equation. Set 1 is taken from Reference 4 , and the rate of crack growth is everywhere larger than the data of Section XI of the ASME, BSPV Code. Set 2 is identical with the first except that the fracture toughness is 150 rather than 200 . This incorporates some conservatism for the possibility that the fracture toughness may decrease during the service life of the vessel as a result of neutron irradiation. The two sets are:

Set $1 \quad \begin{aligned} \mathrm{K}_{\mathrm{IC}} & =200 \\ \mathrm{C} & =9.372 \mathrm{E}-06 \\ \mathrm{n} & =2.342 \\ \sigma & =26.7 \\ \alpha & =1.0 \\ \mathrm{R} & =0.0\end{aligned}$

Set 2

$$
\begin{aligned}
\mathrm{K}_{\mathrm{IC}} & =150 \\
\mathrm{C} & =9.372 \mathrm{E}-06 \\
\mathrm{n} & =2.342 \\
\sigma & =26.7 \\
\alpha & =1.0 \\
\mathrm{R} & =0.0
\end{aligned}
$$


The service life of the vessel as used here is expressed in cycles, for example, 600 and 1000 , rather than in units of time. Again, these values are presumed to be very long and conservative. For example, in the studies given in Reference 5, the 40-year service life of the reactor system consists of 360 stress cycles.

Computer Program II is used to calculate the probability of vessel failure during its service life with only a preservice inspection and repair. The calculation is made in exact accordance with the equations and theory developed in the previous sections. No assumption is made concerning the proportionality of the probability of failure to the mean number of cracks larger than 0.2 inch per vessel. This program does indeed show that the proportionality holds when the mean number of cracks greater than 0.2 inch is less than about 5. Because the assumption is a good one for all cases of interest, it is used in Computer Programs III and IV. Computer Program II shows that the probability of failure approaches unity when the mean number of cracks per vessel approaches infinity.

Computer Program III is used to calculate the factor of improvement in the failure probability when an arbitrary inspection schedule is entered as input. The factor of improvement is defined as the ratio of the probability of failure when the only inspection is the preservice one before the vessel is placed in service to the probability of failure when one or more inservice inspections are made.

The data obtained by the use of this program show that the factor of improvement is very sensitive to the times of the inservice inspections. In general, much larger factors of improvement are obtained when the inspections are conducted during the early parts of the service life. This is in marked contrast to spacing the inspection uniformly over the service life.

Figure 4 shows an example of the dependence of the factor of improvement upon the time of the inspection. This graph is for one inservice inspection only, because it is difficult to show graphically more than two dimensions. However, the same general characteristics apply to two or more inservice inspections. The notable features are the sharpness of the peak or maximum and the rapid decline beyond the peak. The factor of improvement of 64 at zero cycles is what would result from two inspections rather than one just before placing the vessel in service. At the halfway point of 500 cycles, the factor of improvement has fallen from a maximum of 234 to 80 . A schedule that spaces the inservice inspections uniformly over the service life wastes time and is very inefficient. In many cases, it would be better to make only two inservice inspections, optimally spaced, rather than three inservice inspections spaced at 25,50 , and $75 \%$ of the service 1 ife. 


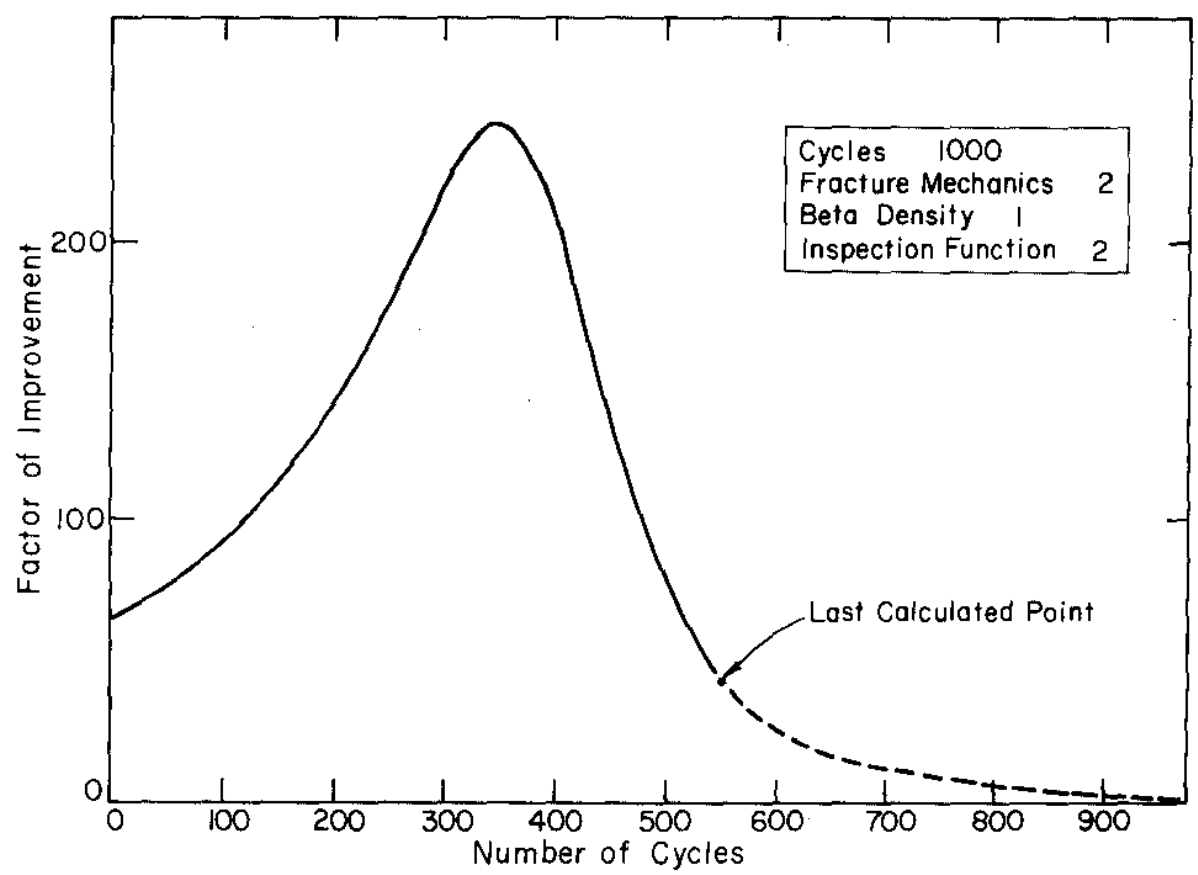

FIGURE 4. Factor of Improvement as Function of Inspection Time

The discovery that the factor of improvement is so strongly dependent upon the inspection schedule pointed out the need for an optimization method, preferably a computer program. It is relatively easy to optimize the schedule when there is only one inservice inspection as shown in Figure 3. But when two or more inspections are involved, the multidimensional task of trial and error becomes too time-consuming and inefficient.

Computer Program IV is used to calculate the optimum schedule for any number of inservice inspections. The program operates to find the one schedule that will result in the largest factor of improvement. The program is an iterative one.

A complete listing of calculations for all combinations of assumptions is given in Tables 1-4. The features mentioned in the earlier discussion are all apparent from these results. Table 4 is not complete because some of the optimum schedules are not listed; however, values have been filled in for the probabilities of failure and the factors of improvement for all cases. These latter quantities were all estimated by the methods described in the following paragraphs. These estimates are all expected to be slightly on the low side; they were in all instances when the exact calculations were made. 
When all other conditions are held constant, the factor of improvement is nearly exponential with the number of inservice inspections. This empirical observation is expressed as: Factor of improvement $(\mathrm{FI})=\exp [\alpha \times$ number of inspections $(\mathrm{NI})]$.

The following data are derived from Tables 1-4:

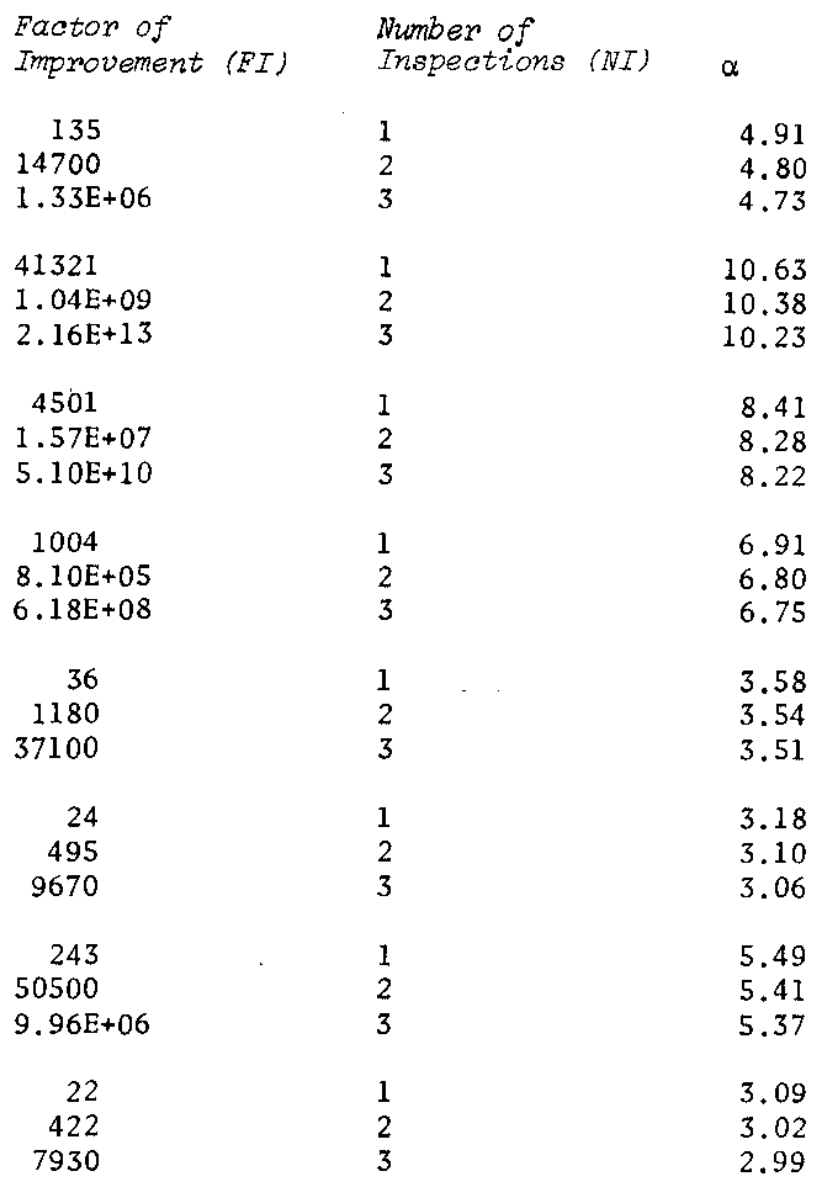

The above data show that even conservative assumptions about the materials and the operating conditions lead to the result that $\alpha$ is 3.0 or greater. This conservative value for $\alpha$ corresponds to sizable factors of improvement as a result of inservice inspection. For example, typical factors of improvement should be in excess of:

$\begin{array}{lc}\text { Number of } & \text { Eactor } \\ \text { Inspections (NI) } & \text { Improv } \\ 1 & 20 \\ 2 & 400 \\ 3 & 8100\end{array}$


TABLE $1^{a}$

Some Numerical Examples

\begin{tabular}{|c|c|c|c|c|c|c|c|c|}
\hline $\begin{array}{l}\text { Fracture } \\
\text { Mechanics }\end{array}$ & $\begin{array}{l}\text { Beta } \\
\text { Density }\end{array}$ & $\begin{array}{l}\text { Inspection } \\
\text { Function }\end{array}$ & $\begin{array}{l}\text { Mean } \\
\text { Number } \\
\text { of Cracks } \\
\text { per } \\
\text { Vessel }\end{array}$ & $\begin{array}{l}\text { Total } \\
\text { Cyctes }\end{array}$ & $\begin{array}{l}\text { Fraction } \\
\text { of Cracks } \\
\text { After } \\
\text { Inspection }\end{array}$ & $\begin{array}{l}\text { Size } \\
\text { That } \\
\text { Grows } \\
\text { Through } \\
\text { Wazl }\end{array}$ & $\begin{array}{l}\text { Probability } \\
\text { No } \\
\text { Inspection }\end{array}$ & $\begin{array}{l}\text { of Eailure } \\
\text { Presemiae } \\
\text { Inspection }\end{array}$ \\
\hline 1 & 1 & 1 & 0.018 & 600 & 0.308 & 4.35 & $2.06 \mathrm{E}-06$ & $2.85 E-08$ \\
\hline 1 & 1 & 1 & 0.050 & 600 & 0.308 & 4.35 & $5.72 \mathrm{E}-06$ & $7.93 E-08$ \\
\hline 1 & 1 & 2 & 0.018 & 600 & 0.322 & 4.35 & $2.06 E-06$ & $2.41 \mathrm{E}-10$ \\
\hline 1 & 1 & 2 & 0.050 & 600 & 0.322 & 4.35 & $5.72 \mathrm{E}-06$ & $6.70 \mathrm{E}-10$ \\
\hline 1 & 2 & 1 & 0.018 & 600 & 0.283 & 4.35 & $2.90 \mathrm{E}-05$ & $3.79 \mathrm{E}-07$ \\
\hline 1 & 2 & 1 & 0.050 & 600 & 0.283 & 4.35 & $8.07 E-05$ & $1.05 E-06$ \\
\hline 1 & 2 & 2 & 0.018 & 600 & 0.290 & 4.35 & $2.90 \mathrm{E}-05$ & $2.91 E-09$ \\
\hline 1 & 2 & 2 & 0.050 & 600 & 0.290 & 4.35 & $8.07 E-05$ & 8.10E-09 \\
\hline 1 & 1 & 1 & 0.018 & 1000 & 0.308 & 3.05 & $4.92 \mathrm{E}-05$ & $1.28 \mathrm{E}-06$ \\
\hline 1 & 1 & 1 & 0.050 & 1000 & 0.308 & 3.05 & 1. $37 \mathrm{E}-04$ & $3.56 \mathrm{E}-06$ \\
\hline 1 & 1 & 2 & 0.018 & 1000 & 0.322 & 3.05 & $4.92 \mathrm{E}-04$ & $4.63 \mathrm{E}-08$ \\
\hline 1 & 1 & 2 & 0.050 & $1000^{\circ}$ & 0.322 & 3.05 & $1.37 \mathrm{E}-04$ & $1.29 \mathrm{E}-07$ \\
\hline 1 & 2 & 1 & 0.018 & 1000 & 0.283 & 3.05 & $2.53 \mathrm{E}-04$ & $6.09 E-06$ \\
\hline 1 & 2 & 1 & 0.050 & 1000 & 0.283 & 3.05 & $7.01 E \sim 04$ & $1.69 \mathrm{E}-05$ \\
\hline 1 & 2 & 2 & 0.018 & 1000 & 0.290 & 3.05 & $2.53 E-04$ & $2.00 \mathrm{E}-07$ \\
\hline 1 & 2 & 2 & 0.050 & 1000 & 0.290 & 3.05 & $7.01 \mathrm{E}-04$ & $5.55 E-07$ \\
\hline 2 & 1 & 1 & 0.018 & 600 & 0.308 & 2.45 & $1.74 E-04$ & $6.31 E-06$ \\
\hline 2 & 1 & 2 & 0.050 & 600 & 0.308 & 2.45 & $4.84 E-04$ & $1.75 \mathrm{E}-05$ \\
\hline 2 & 1 & 2 & 0.018 & 600 & 0.322 & 2.45 & 1. $74 \mathrm{E}-04$ & $4.47 \mathrm{E}-07$ \\
\hline 2 & I & 2 & 0.050 & 600 & 0.322 & 2.45 & $-4 \times 84 \mathrm{E}-04$ & $1.24 \mathrm{E}-06$ \\
\hline 2 & 2 & 1 & 0.018 & 600 & 0.283 & 2.45 & $6.04 E-04$ & $2.01 \equiv-05$ \\
\hline 2 & 2 & 1 & 0.050 & 600 & 0.283 & 2.45 & $1.68 \mathrm{E}-03$ & $5.57 \mathrm{E}-05$ \\
\hline 2 & 2 & 2 & 0.018 & 600 & 0.290 & 2.45 & $6.04 \mathrm{E}-04$ & $1.29 \mathrm{E}-06$ \\
\hline 2 & 2 & 2 & 0.050 & 600 & 0.290 & 2.45 & 1. $68 \mathrm{E}-03$ & $3.59 \mathrm{E}-06$ \\
\hline 2 & 1 & 1 & 0.018 & 1000 & 0.308 & 1.60 & $9.44 E-04$ & $5.91 \mathrm{E}-05$ \\
\hline 2 & 1 & 1 & 0.050 & 1000 & 0.308 & 1.60 & $2.62 \mathrm{E}-08$ & $1.04 E-04$ \\
\hline 2 & 1 & 2 & 0.018 & 1000 & 0.322 & 1.60 & $9.44 \mathrm{E}-04$ & $1.12 \mathrm{E}-05$ \\
\hline 2 & 1 & 2 & 0.050 & 1000 & 0.322 & 1.60 & $2.62 \mathrm{E}-03$ & $3.12 E-05$ \\
\hline 2 & 2 & 1 & 0.018 & 1000 & 0.205 & 1.60 & $1.96 \mathrm{E}-03$ & $1.11 \mathrm{E}-04$ \\
\hline 2 & 2 & 1 & 0.050 & 1000 & 0.283 & 1.60 & $5.43 \mathrm{E}-03$ & $3.09 \mathrm{E}-04$ \\
\hline 2 & 2 & 2 & 0.018 & 1000 & 0.290 & 1.60 & $1.96 \mathrm{E}-03$ & $1.93 \mathrm{E}-\mathrm{us}$ \\
\hline 2 & 2 & 2 & 0.050 & 1000 & 0.290 & 1.60 & $5.43 \mathrm{E}-03$ & $5.37 \mathrm{E}-0 \mathrm{~S}$ \\
\hline
\end{tabular}

a. Tables 1 through 4 are intended to be continuous when placed side by side. The $n^{\text {th }}$ line is continued from table to table to represent a single case. 
TABLE 2

NUMERICAL EXAMPLES FOR ONE INSERVICE INSPECTION

\begin{tabular}{|c|c|c|c|c|c|}
\hline Sycles & $\begin{array}{l}\text { Probability } \\
\text { of Eailure }\end{array}$ & $\begin{array}{l}\text { Eactor of } \\
\text { Improvement }\end{array}$ & Cyoles & $\begin{array}{l}\text { Probability } \\
\text { of Failure }\end{array}$ & $\begin{array}{l}\text { Factor of } \\
\text { Improvement }\end{array}$ \\
\hline 300 & $2.28 E-10$ & 125 & 267 & $2.11 \mathrm{E}-10$ & 135 \\
\hline 300 & $6.33 E-10$ & 125 & 267 & $5.86 \mathrm{E}-10$ & 135 \\
\hline 300 & $7.35 \mathrm{E}-14$ & 3281 & 212 & $5.83 \mathrm{E}-15$ & 41321 \\
\hline 300 & $2.04 \mathrm{E}-13$ & 3281 & 212 & $1.62 \mathrm{E}-14$ & 41321 \\
\hline 300 & $6.64 E-09$ & 57 & 201 & $3.24 E-09$ & 117 \\
\hline 300 & $1.84 \mathrm{E}-08$ & 57 & 201 & $8.98 \mathrm{E}-09$ & 117 \\
\hline 300 . & $5.44 E-12$ & 536 & 162 & $1.06 \mathrm{E}-13$ & 27357 \\
\hline 300 & $1.51 \mathrm{E}-11$ & 536 & 162 & $2.96 \mathrm{E}-13$ & 27357 \\
\hline 500 & $1.85 \mathrm{E}-08$ & 69 & 434 & $1.64 \mathrm{E}-08$ & 78 \\
\hline 500 & $5.13 \mathrm{E}-08$ & 69 & 434 & $4.55 E-08$ & 78 \\
\hline 500 & $3.35 E-11$ & 1382 & 382 & $6.97 E-12$ & 6641 \\
\hline 500 & $9.30 \mathrm{E}-11$ & 1382 & 382 & $1.94 \mathrm{E}-11$ & 6641 \\
\hline 500 & $1.80 \mathrm{E}-07$ & 34 & 334 & $9.10 E-08$ & 67 \\
\hline 500 & $5.00 \mathrm{E}-07$ & 34 & 334 & $2.53 \mathrm{E}-07$ & 67 \\
\hline 500 & $5.93 \mathrm{E}-10$ & 337 & 314 & $4.44 E-11$ & 4501 \\
\hline 500 & $1.65 \mathrm{E}-09$ & 337 & 314 & $1.23 \mathrm{E}-10$ & 4501 \\
\hline 300 & $2.77 \mathrm{E}-07$ & 23 & 194 & $1.58 \mathrm{E}-07$ & 40 \\
\hline 300 & $7.70 \mathrm{E}-07$ & 23 & 194 & $4.38 \mathrm{E}-07$ & 40 \\
\hline 300 & $3.13 \mathrm{E}-09$ & 143 & 187 & $4.45 E-10$ & 1004 \\
\hline 300 & $8.09 \mathrm{E}-09$ & 143 & 187 & 1. $24 \mathrm{E}-09$ & 1004 \\
\hline 300 & $1.72 \mathrm{E}-06$ & 12 & 132 & $5.35 \mathrm{E}-07$ & 36 \\
\hline 300 & $4.78 \mathrm{E}-06$ & 12 & 132 & $1.54 \mathrm{E}-06$ & 36 \\
\hline 300 & $2.21 \mathrm{E}-08$ & 58 & 147 & $1.64 \mathrm{E}-09$ & 786 \\
\hline 300 & $6.15 \mathrm{E}-08$ & 58 & 147 & $4.57 E-09$ & 786 \\
\hline 500 & $4.01 \mathrm{E}-06$ & 15 & 329 & $2.47 \mathrm{E}-06$ & 24 \\
\hline 500 & $1.11 \mathrm{E}-05$ & 15 & 329 & $6.86 \mathrm{E}-06$ & 24 \\
\hline 500 & $1.41 \mathrm{E}-07$ & 80 & 352 & $4.61 \mathrm{E}-08$ & 243 \\
\hline 500 & $3.91 \mathrm{E}-07$ & 80 & 352 & 1. $28 \mathrm{E}-07$ & 243 \\
\hline 500 & $1.22 \mathrm{E}-05$ & 9 & 236 & $5.14 \mathrm{E}-06$ & 22 \\
\hline 500 & $3.52 E-05$ & 9 & 236 & $1.43 E-05$ & 22 \\
\hline 500 & $4.79 \mathrm{E}-07$ & 40 & 297 & $9.85 \mathrm{E}-08$ & 196 \\
\hline 500 & 1. $33 E-06$ & 40 & 297 & $2.74 \mathrm{E}-07$ & 196 \\
\hline
\end{tabular}


TABLE 3

Numerical Examples for Two Inservice Inspections

\begin{tabular}{|c|c|c|c|c|c|}
\hline Cycles & $\begin{array}{l}\text { Probability } \\
\text { of Failure }\end{array}$ & $\begin{array}{l}\text { Factor of } \\
\text { Improvement }\end{array}$ & Cycles & $\begin{array}{l}\text { Probability } \\
\text { of Failure }\end{array}$ & $\begin{array}{l}\text { Eactor of } \\
\text { Improvement }\end{array}$ \\
\hline 200,400 & $5.68 \mathrm{E}-12$ & 5030 & 162,294 & $1.94 \mathrm{E}-12$ & 14700 \\
\hline 200,400 & $1.58 \mathrm{E}-11$ & 5030 & 162,294 & $5.39 \mathrm{E}-12$ & 14700 \\
\hline 200,400 & $4.29 \mathrm{E}-16$ & $5.02 E+05$ & 93,271 & $2.32 \mathrm{E}-19$ & $1.04 \mathrm{E}+09$ \\
\hline 200,400 & $1.19 \mathrm{E}-15$ & $5.02 E+05$ & 93,271 & $6.44 E-19$ & $1.04 E+09$ \\
\hline 200,400 & $3.87 \mathrm{E}-10$ & 979 & 101,234 & $3.32 \mathrm{E}-11$ & 11400 \\
\hline $200,400^{\circ}$ & $1.07 \mathrm{E}-09$ & 979 & 101,234 & $9.21 \mathrm{E}-11$ & 11400 \\
\hline 200,400 & $1.17 \mathrm{E}-13$ & $2.50 \mathrm{E}+04$ & 52,232 & $5.31 \mathrm{E}-18$ & $5.48 E+08$ \\
\hline 200,400 & $3.24 \mathrm{E}-13$ & $2.50 E+04$ & 52,232 & $1.48 \mathrm{E}-17$ & $5.48 \mathrm{E}+08$ \\
\hline 333,666 & $6.98 \mathrm{E}-10$ & 1835 & 262,495 & $2.63 \mathrm{E}-10$ & 4810 \\
\hline 333,666 & 1. $94 \mathrm{E}-09$ & 1835 & 262,495 & 7. $31 E-10$ & 4810 \\
\hline 333,666 & $2.66 \mathrm{E}-13$ & $1.74 \mathrm{E}+05$ & 184,499 & $1.59 \mathrm{E}-15$ & $2.92 \mathrm{E}+07$ \\
\hline 333,666 & $7.39 \mathrm{E}-13$ & 1. $74 \mathrm{E}+05$ & 184,499 & $4.42 \mathrm{E}-\mathrm{I} 5$ & $2.92 \mathrm{E}+07$ \\
\hline 333,666 & $1.39 E-08$ & 439 & 170,408 & $1.63 \mathrm{E}-09$ & 3730 \\
\hline 333,666 & $3.86 \mathrm{E}-08$ & 439 & 170,408 & $4.53 E-09$ & 3730 \\
\hline 333,666 & $1.44 E-11$ & 13800 & 122,450 & $1.27 E-14$ & $1.57 \mathrm{E}+07$ \\
\hline 333,666 & $4.01 \mathrm{E}-11$ & 13800 & 122,450 & $3.54 \mathrm{E}-14$ & $1.57 E+07$ \\
\hline 200,400 & $2.89 \mathrm{E}-08$ & 218 & 95,238 & $4.57 \mathrm{E}-09$ & 1380 \\
\hline 200,400 & $8.03 \mathrm{E}-08$ & 218 & 95,238 & $1.27 E-08$ & 1380 \\
\hline 200,400 & $1.33 \mathrm{E}-10$ & 3357 & 73,265 & $5.52 \mathrm{E}-13$ & $8.10 \mathrm{E}+05$ \\
\hline 200,400 & 3. $70 \mathrm{E}-10$ & 3357 & 73,265 & $1.53 \mathrm{E}-12$ & $8.10 E+05$ \\
\hline 200,400 & $3.22 \mathrm{E}-07$ & 62 & 48,183 & I. $70 \mathrm{E}-08$ & 1180 \\
\hline 200,400 & $8.95 E-07$ & 62 & $48, \quad 183$ & $4,72 E-08$ & 1180 \\
\hline 200,400 & $1.81 \mathrm{E}-09$ & 714 & 42,236 & $2.29 E-12$ & $5.04 E+05$ \\
\hline 200,400 & $5.03 \mathrm{E}-09$ & 714 & 42,236 & $6.37 \mathrm{E}-12$ & $5.64 \mathrm{E}+05$ \\
\hline 333,666 & $5.22 \mathrm{E}-07$ & 113 & 169,419 & 1. $19 \mathrm{E}-07$ & 495 \\
\hline 333,666 & $1.45 \mathrm{E}-06$ & 113 & 169,419 & $3.31 \mathrm{E}-07$ & 495 \\
\hline 333,666 & $6.95 \mathrm{E}-09$ & 1617 & 160,491 & $2.22 \mathrm{E}-10$ & 50500 \\
\hline 333,666 & $1.93 \mathrm{E}-08$ & 1617 & 160,491 & $6.18 \mathrm{E}-10$ & 50500 \\
\hline 333,666 & $2.07 \mathrm{E}-06$ & 42 & 95,340 & $2.03 \mathrm{E}-07$ & 422 \\
\hline 333,666 & $7.42 \mathrm{E}-06$ & 42 & 95,340 & $7.32 \mathrm{E}-07$ & 422 \\
\hline 333,666 & $4.19 \mathrm{E}-08$ & 461 & 111,453 & $5.76 \mathrm{E}-10$ & 36000 \\
\hline 333,666 & $1.16 \mathrm{E}-07$ & 461 & 111,453 & $1.49 E-09$ & 36000 \\
\hline
\end{tabular}


TABLE 4

Numerical Examples for Three Inservice inspections

\begin{tabular}{|c|c|c|c|c|c|}
\hline Cycles & $\begin{array}{l}\text { Probability } \\
\text { of Eailure }\end{array}$ & $\begin{array}{l}\text { Factor of } \\
\text { Improvement }\end{array}$ & Cycles & $\begin{array}{l}\text { Probability } \\
\text { of Failure }\end{array}$ & $\begin{array}{l}\text { Factor of } \\
\text { Improvement }\end{array}$ \\
\hline $150,300,450$ & $3.05 \mathrm{E}-13$ & 93600 & $104,183,316$ & $1.98 \mathrm{E}-14$ & $1.44 \mathrm{E}+06$ \\
\hline $150,300,450$ & $8.47 \mathrm{E}-13$ & 93600 & $104,183,316$ & $5.51 \mathrm{E}-14$ & 1. $44 \mathrm{E}+06$ \\
\hline $150,300,450$ & $9.84 \mathrm{E}-18$ & $2.45 E+07$ & $43,134,315$ & $1.12 \mathrm{E}-23$ & $2.16 E+13$ \\
\hline $150,300,450$ & $2.74 \mathrm{E}-17$ & $2.45 \mathrm{E}+07$ & $43,134,315$ & $3.10 \mathrm{E}-23$ & $2.26 E+13$ \\
\hline $150,300,450$ & $4.46 E-11$ & 8505 & & $4.09 \mathrm{E}-13$ & $9.27 \mathrm{E}+05$ \\
\hline $150,300,450$ & $1.24 \mathrm{E}-10$ & 8505 & & $1.13 \mathrm{E}-12$ & $9.27 \mathrm{E}+05$ \\
\hline $150,300,450$ & $7.36 \mathrm{E}-15$ & $3.96 E+06$ & & $3.07 \mathrm{E}-22$ & $7.92 E+12$ \\
\hline $150,300,450$ & $2.05 E-14$ & $3.96 \mathrm{E}+06$ & & $1.02 \mathrm{E}-21$ & $7.92 \mathrm{E}+12$ \\
\hline $250,500,750$ & $5.08 \mathrm{E}-11$ & 25200 & & $5.16 \mathrm{E}-12$ & $2.48 \mathrm{E}+0.5$ \\
\hline $250,500,750$ & $1.41 E-10$ & 25200 & & $1.44 E-11$ & $2.48 \mathrm{E}+05$ \\
\hline $250,500,750$ & $7.48 \mathrm{E}-15$ & $6.19 E+06$ & & $5.59 E-19$ & $8.28 \mathrm{E}+10$ \\
\hline $250,500,750$ & $2.08 \mathrm{E}-14$ & $6.19 E+06$ & & $1.56 \mathrm{E}-18$ & $8.20 \mathrm{E}+10$ \\
\hline $250,500,750$ & $1.94 \mathrm{E}-09$ & 3146 & & $3.52 \mathrm{E}-11$ & $1.73 E+05$ \\
\hline $250,500,750$ & $5.88 \mathrm{E}-09$ & 3146 & & $9.77 \mathrm{E}-11$ & $1.73 E+05$ \\
\hline $250,500,750$ & $9.76 E-13$ & $2.05 E+06$ & $49,219,542$ & $3.92 \mathrm{E}-18$ & $5.10 E+10$ \\
\hline $250,500,750$ & $2.71 \mathrm{E}-12$ & $2.05 E+06$ & $49,219,542$ & $1.09 \mathrm{E}-17$ & $5.10 \mathrm{E}+10$ \\
\hline $150,300,450$ & $5.15 \mathrm{E}-09$ & 1227 & & $1.59 \mathrm{E}-10$ & $3.97 E+04$ \\
\hline $150,300,450$ & $1.43 E-08$ & 1227 & & $4.41 E-10$ & $3.97 E+01$ \\
\hline $150,300,450$ & $1.86 \mathrm{E}-11$ & 33000 & $29,130,319$ & $7.23 \mathrm{E}-16$ & $6.18 \mathrm{E}+08$ \\
\hline $150,300,450$ & $3.68 \mathrm{E}-11$ & 33000 & $29,130,319$ & $2.01 \mathrm{E}-15$ & $6.18 E+08$ \\
\hline $150,300,450$ & $9.31 E-08$ & 216 & $19,76,226$ & $5.42 \mathrm{E}-10$ & $3.71 E+04$ \\
\hline $150,300,450$ & $2.59 \mathrm{E}-07$ & 216 & $19,76,226$ & $1.50 \mathrm{E}-09$ & $3.71 E+04$ \\
\hline $150,300,450$ & $3.03 E-10$ & 4269 & & $3.55 \mathrm{E}-15$ & $3.63 E+08$ \\
\hline $150,300,450$ & $8.41 \mathrm{E}-10$ & 4269 & & $9.89 \mathrm{E}-15$ & $3.63 E+08$ \\
\hline $250,500,750$ & $1.06 \mathrm{E}-07$ & 555 & $94,233,488$ & $6.11 E-09$ & 9670 \\
\hline $250,500,750$ & $2.96 \mathrm{E}-07$ & 555 & $94,233,488$ & $1.70 \mathrm{E}-08$ & 9670 \\
\hline $250,500,750$ & $7.66 \mathrm{E}-10$ & 14700 & $77,274,581$ & $1.12 \mathrm{E}-12$ & $9.96 \mathrm{E}+06$ \\
\hline $250,500,750$ & $7.13 \mathrm{E}-09$ & 14700 & $77,274,581$ & $3.13 \mathrm{E}-12$ & $9.96 \mathrm{E}+06$ \\
\hline $250,500,750$ & $8.27 \mathrm{E}-07$ & 134 & $42,158,424$ & $1.40 \mathrm{E}-08$ & 7930 \\
\hline $250,500,750$ & $2.30 \mathrm{E}-06$ & 134 & $42,158,421$ & $3.90 \mathrm{E}-08$ & 7930 \\
\hline $250,500,750$ & $7.21 E-09$ & 2680 & & $3.05 \mathrm{E}-12$ & $6.32 \mathrm{E}+06$ \\
\hline $250,500,750$ & $2.00 \mathrm{E}-08$ & 2680 & & $8.50 \mathrm{E}-12$ & $6.32 E+06$ \\
\hline
\end{tabular}




\section{REFERENCES}

1. Technical Report on Analysis of Pressure Vessel Statistics from Eossil-Fueled Power Plant Service and Assessment of Reactor Vessel Reliability in Nuclear Power Service. USAEC Report WASH-1318, USAEC Regulatory Staff, Washington, DC (May 1974).

2. Report on the Integrity of Reactor Vessels for Light-Water Power Reactors. USAEC WASH-1285, USAEC Advisory Committee on Reactor Safeguards, Washington, DC (January 1974).

3. G. J. Hahn and. S. S. Shapiro. Statistical Methods in Engineering. John Wiley, New York (1968).

4. C. Y. Cheng, U.S. Nuclear Regulatory Commission. "The Fatigue Crack Growth of ASTM A533 Grade B Class 1 Steel" (Personal Communication).

5. S. A. Wilson. Estimating Pipe Reliability Distribution of Time-to-Damage Method. USAEC Report GEAP-10452, Genera1 Electric Company, Atomic Power Equipment Department, San Jose, CA (March 1972). 